\title{
Testing Growth Theory Using Existing Growth Models for MENA Countries
}

\author{
Mohamed Omar Fargani ${ }^{1}$ \& Girijasankar Mallik ${ }^{2}$ \\ ${ }^{1}$ Department of Business Administration and Accounting, AL Buraimi University College, Oman \\ ${ }^{2}$ School of Economics and Finance, University of Western Sydney, Australia \\ Correspondence: Department of Business Administration and Accounting, AL Buraimi University College, \\ Oman. E-mail: MFargani@buc.edu.om
}

Received: August 30, 2020

Accepted: October 26, 2020

Online Published: October 28, 2020

doi:10.5539/ijef.v12n11p151

URL: https://doi.org/10.5539/ijef.v12n11p151

\begin{abstract}
This paper examines the growing gap between the theoretical and empirical growth literature and policy needs of the developing economies. Growth literature has focused mainly on long term growth outcomes, but policy makers of the developing economies need rapid improvements in the short to medium term growth rates. In this paper we argue that this gap can be reduced by distinguishing between the short to medium term dynamic effects of policies from their long run equilibrium effects. With data from selected 15 MENA countries; we show that an extended version of the Solow (1956) model is well suited for this purpose. We include the education find that the short to medium term growth effects of the investment ratio are quite significant and they may persist for up to 10 years.
\end{abstract}

Keywords: Solow growth model, endogenous growth, dynamic growth effects of investment ratio, policies for developing countries

\section{Introduction}

Only a few empirical studies have dealt with the MENA region largely due to lack of data. However, as data became available for some countries of the region, some researchers have addressed these countries in the context of a large sample. Among the early studies to estimate the physical stocks and analysis the source of growth is that Nehru and Dhareshwar (1993), Aamer, Abu-Quarn, and Abu-Bader (2007). They used different methods to estimate physical capital and to estimate the production function.

One the most notable and broadly-shared characteristics of MENA economics is the fast growth of population and the increase of labour force. From 1980s until 1990s the economic growth in MENA still unchanged because of the collapse in investment and instability of macroeconomic variables in the region (Keller \& Nabli, 2002). In addition, in 2000 s there is increase of public investment in infrastructure, health and education was able to translate into high growth of GDP.

In terms of labour market, the World Bank (2004) has documented that MENA's total labour force has been experiencing an unprecedented expansion - from 104 million workers in 2000 to an estimated by 146 million by 2010 and to an expected 185 million by 2020 . So, it is so hard for these countries to create the millions of job needed to absorb this rapid expansion of work force, resulting in the region experiencing the highest level of unemployment in the world. Additionally, the growth contribution of labour seems to have been rising over time because of a general acceleration in labour supply growth in the region over the last period (Esfahani, 2008).

Another salient feature of the recent growth of real GDP performance of MENA countries is its high volatility. It is shown in the Appendix B that during the period 1970-1980, the average of real GDP growth of MENA countries has been characterized by a high variability. On the other hand, the average of real GDP in MENA oil-exporters countries is much more volatile than the non-oil countries.

\section{Model Specification and Data Description}

The analytical framework of this study is discussed in four sub-sections. We specify the production function for long-run and short-run for fifteen MENA countries in the first section, followed by the definition of the variables in the model and the sources of our data. The third section presents the review of estimation techniques for the study of production function, and concluding remarks are provided in the fourth section. 


\subsection{Definition of Variables and Data Sources}

Our sample of 15 MENA countries including (Algeria, Bahrain, Egypt, Iran, Israel, Jordan, Kuwait, Libya, Morocco, Oman, Qatar, Saudi Arabia, Syria, Tunisia and United Arab Emirates covering the period 1970 to 2010. To estimate the production function in MENA region, however, data on some key variables are not available for all the countries and hence our panel data is unbalanced. In addition details of the data are in the appendix.

Most data come from the World Bank, IMF, KLM, Penn World Tables 5.6 (PWT5.6) and our own calculations. From Barro and Lee (2012), we obtain educational attainment dataaverage years of schooling for deferent category (primary, secondary and tertiarywhich are available from 1960-2010) (Note 1).

\subsection{Exogenous Growth Theory}

A macroeconomic production function is a mathematical expression that describes a systematic relationship between inputs and output in an economy and the Cobb-Douglas is function that has been used extensively. This function plays an important role in the economic forecasts and policy analysis.

The neo-classical growth model is also known as the exogenous growth model or Solow growth model. The Solow model was developed by Nobel Prize winner Robert Solow. In Solow's model, there are two factors of production: capital and labour. Technology is exogenous and represented by production function:

$$
Y=F(K, L)
$$

Where $\boldsymbol{Y}$ is output or real GDP, $\boldsymbol{F}$ the function of technology, $\boldsymbol{K}$ capital stock input, and $\boldsymbol{L}$ labour input.

A sustained increase in capital investment increases the growth rate only temporarily: the capital/labour ratio goes up. Steady-State growth path is reached when output, capital and labour are all growing at the same rate. These factors include, among others, technology level, quality of labour (human capital) which we use depending on our availability of data the government spending on health and education.

\subsection{Measurement of Inputs}

The neo-classical growth model is also known as the exogenous growth model or Solow growth model. In Solow's model, there are two factors of production: capital and labour.

\subsubsection{Measurement of Capital Stock $(K)$}

Of particular note is our use of a new dataset on capital stocks. The relevant reference concerning the construction of these capital stock estimates is Nehru and Dhareshwar (1993), and the dataset is available as part of the World Bank's STARS databank and other sources as shown in Appendix B. investment at constant local prices and draws on additional data sources. They show that their capital stock estimates are positively correlated with other inputs.

\subsubsection{Labour $(L)$}

Labour force is measured in millions and the series ranges from 1970 to 2010, and we used it in our measure as the growth of labour. All selected variables were in U.S dollar and in constant prices of 2005.

\section{Education as Include in Calculation of Growth $(E D U)$}

As the present study confines itself to the growth of MENA region, thus, I shall concentrate on the secondary education category as a proxy for human capital development of the labour force in the economy.

\subsection{Model Specification}

This study examines the relationship between real growth of GDP and the growth of inputs factors (capital and Labour) using time series data for 15 MENA countries. The real GDP data was in real terms, with 2005 as the base year. Most of the three variables have unit root and non-stationary. The variables tend to show similar increasing or decreasing pattern over time. Hence, before proceeding with further analysis, the data must be tested for existence of unit roots using various tests available in the econometrics literature.

According to the literature above, generally the Cobb-Douglas function can be as following

Where

$$
Y_{t}=A K^{\alpha}{ }_{t} L^{1-\alpha}
$$

$Y$ is the real GDP; $K$ is the capital input; $L$ is the labour input; $A$ is the technology.

\subsection{Estimated}

In our study we utilize three methods. First, we use cross section-data techniques to estimate the capital stock. Second, we relax this assumption and estimate the parameters of the production function separately for every 
country based on identifying the long-run and short-run relationship between output and inputs by applying the Johansen Co-integration and Error Correction Model (ECM). Third, we conduct Impulse Response Function on our estimated to represent the behaviour of growth of real GDP, growth of capital and growth of labour.

\subsection{Diagnostic Tests}

As argued in the literature, we have to take into account the potential non-stationarity in the data; the following two step estimation strategy has been adopted:

First, test the three variables real GDP, stock of capital and labour in production function for presence of unit root.

\subsubsection{Results of Unit Root Test}

The results of Augmented Dicky-Fuller (ADF) test is presented in (AppendixD). From ADF test, we can conclude that $R G D P$ on level is none stationary or integrated of order one I(1) for some countries, and the unit root of null hypothesis on the level can be rejected at 10 per cent or less only for three countries; Algeria, Bahrain and Syria. Also we take first difference; we fail to reject the null hypothesis for the same countries. For $\ln K$, the unit-root hypothesis on the level or first difference can be rejected at 5 per cent for the following five countries: Algeria, United Arab Emirates, Saudi Arabia, Oman and Kuwait. For $\ln L$, the unit-root of null hypothesis on the level and first difference can be rejected at 5 per cent for eight countries: Algeria, Bahrain, Egypt, Israel, Morocco, Oman, Saudi Arabia and United Arab Emirates.

\subsubsection{Co-Integration Testing}

The idea of using co-integration is that two or more variables may be regarded as defining a long-run equilibrium relationship if they move closely together in the together in the long run, even though they may drift apart in the short run. This long-run relationship is referred to as a co-integrating vector. Because there is a long-run relationship between the variables, a regression containing all the variables of a co-integrating vector will have a stationary error term, even if none of the variables taken alone is stationary. To this end our model for testing the long relationship as following:

$$
\ln Y_{t}=\alpha+\beta_{1} \ln K_{t}+\beta_{2} \ln L_{t}+\varepsilon_{t}
$$

In the case of the relationship among the $\ln Y, \ln K$ and $\ln L$, we conclude that the null hypothesis of no co-integration is strongly rejected. The lag lengths are selected using AICcriteria.

\subsubsection{Dummy Variables}

In order to introduce regional dummy variables in the regressions to correct for the estimation bias due to the restrictive assumption of identical initial technologies for all sample countries, the complete sample of 15 countries is divided into two areas, Oil exporting countries and non-Oil exporting. We used OIL as Dummy variable for oil exporters based on the IMF classification of the countries taking 1 for countries whose fuel exports represent 50\% or more of the total of exports during the period between 1984 and 1986, and 0 others.

\subsubsection{Error Correction Mechanism (ECM)}

The specifications use for estimating the growth effects of one or another growth enhancing variables, in both the cross country and country specific studies, need examination. Although most of these studies claim that they are estimating the permanent long-run growth effects, there is no distinction between the permanent long-run and the transitory short-run growth effects of variables. As we estimated the long-run relationship, also in this section the short-run is important for the policy makers especially of developing countries because of the affect which could be for more than five years and will have permanent level effects; see Rao and Cooray (2009) for more details. To this end, we specify and estimate an Error Correction Mechanism (ECM) appropriate as following:

$$
\Delta \ln Y_{t}=\alpha_{1}+\sum_{i=1}^{p} \beta_{1 i} \Delta \ln K_{t-i}+\sum_{j=1}^{p} \beta_{2 i} \Delta \ln L_{t-j}+\gamma_{1} E D U_{t}+\gamma_{2} I N F_{2}+\gamma_{3} D U M_{t}+\eta_{t} E C M_{t-1}+e_{t}
$$

\subsubsection{Impulse Response Functions}

Finally, we conduct Impulse Response Function (IFR) on our estimated. IFR is a practical way to visually represent the behaviour of RGDP (Y), Stock of Capital (K) and Labour (L) in response to the various shocks. Appendix (A) show figures of our IRF for 15 countries. 
Table 1. Johansen's Co-integration Test and LR test based on maximum Eigen value of stochastic matrix: variables: $\operatorname{lnRGDP}, \operatorname{lnK}$ and $\operatorname{lnL}$

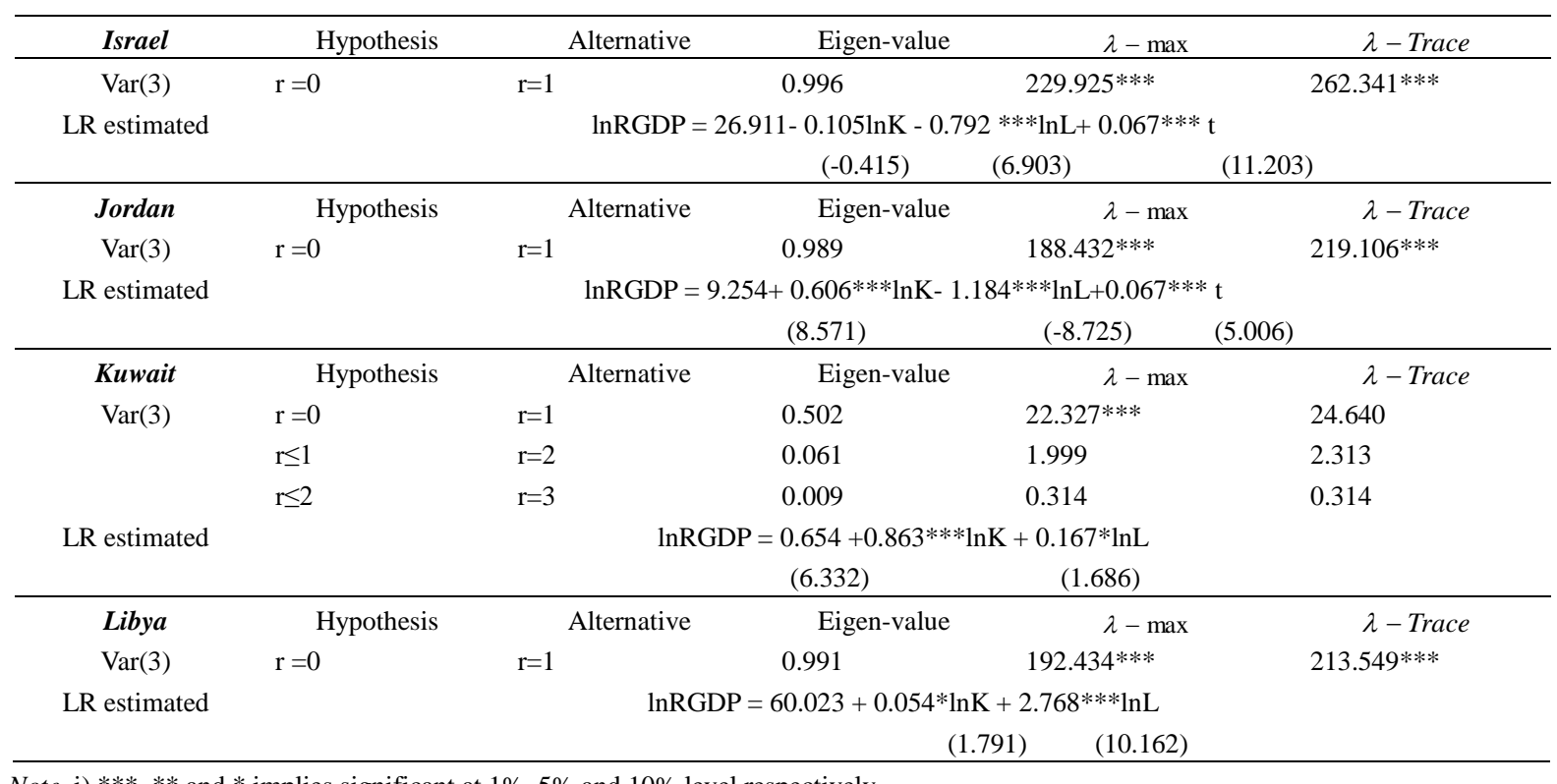

Note. i) ***, ** and * implies significant at $1 \%, 5 \%$ and $10 \%$ level respectively.

ii) Figures in parenthesis represent the t-statistics.

Table 2. Estimated co-efficient using VECM from 1970-2010

\begin{tabular}{|c|c|c|c|c|}
\hline \multicolumn{5}{|c|}{ Dependent variable $=\Delta \ln Y$} \\
\hline & Algeria & Bahrain & Egypt & Iran \\
\hline \multirow[t]{2}{*}{$E C M_{t-1}$} & $0.241 * * *$ & $-0.308 * * *$ & $-0.002 * * *$ & $-0.362 * * *$ \\
\hline & $(3.852)$ & $(41.363)$ & $(-13.085)$ & $(-18.661)$ \\
\hline \multirow{2}{*}{$\Delta \ln Y_{t-1}$} & -0.211 & $0.537 *$ & 0.230 & $0.352^{*}$ \\
\hline & $(-1.250)$ & $(1.880)$ & $(1.320)$ & $(1.673)$ \\
\hline \multirow[t]{2}{*}{$\Delta \ln K_{t-1}$} & $1.262 * *$ & 0.213 & $0.731 * * *$ & $1.620 * *$ \\
\hline & $(2.914)$ & $(0.417)$ & $(3.280)$ & $(1.915)$ \\
\hline \multirow[t]{2}{*}{$\Delta \ln L_{t-1}$} & -1.113 & -0.514 & $0.081 * *$ & $-1.356^{* * *}$ \\
\hline & $(-0.844)$ & $(-1.503)$ & $(2.010)$ & $(-3.122)$ \\
\hline \multicolumn{5}{|c|}{ Exogenous variables } \\
\hline \multirow[t]{2}{*}{ DUM } & 0.005 & -0.031 & 0.011 & -0.006 \\
\hline & $(0.374)$ & $(-0.836)$ & $(1.135)$ & $(-0.239)$ \\
\hline \multirow[t]{2}{*}{ INF } & 0.002 & -0.002 & -0.001 & $-0.004 * *$ \\
\hline & $(1.041)$ & $(-0.566)$ & $(-1.129)$ & $(-2.539)$ \\
\hline \multirow[t]{2}{*}{$E D U$} & $0.042 * * *$ & $0.157 * * *$ & $0.005^{*}$ & $0.109 * * *$ \\
\hline & $(3.484)$ & $(19.685)$ & $(1.630)$ & $(18.328)$ \\
\hline \multirow[t]{2}{*}{ Constant } & $-0.257 * * *$ & $-1.063 * * *$ & 0.013 & $-0.497 * * *$ \\
\hline & $(-2.444)$ & $(-18.095)$ & $(0.674)$ & $(-11.881)$ \\
\hline$R^{2}$ & 0.638 & 0.994 & 0.896 & 0.960 \\
\hline $\operatorname{Adj} \cdot R^{2}$ & 0.504 & $0 . .989$ & 0.862 & 0.941 \\
\hline Standard error & 0.019 & 0.052 & 0.020 & 0.055 \\
\hline AIC & -4.864 & -2.771 & -4.713 & -2.694 \\
\hline F-stat & $4.765 * *$ & $245.618 * * *$ & $25.934 * * *$ & $50.403 * * *$ \\
\hline
\end{tabular}

Note. i) $* * *, * *$ and $*$ implies significant at $1 \%, 5 \%$ and $10 \%$ level respectively.

ii) Figures in parenthesis represent the t-statistics. 
Table 3. Estimated co-efficient using VECM from 1970-2010 (continued)

\begin{tabular}{|c|c|c|c|c|}
\hline \multicolumn{5}{|c|}{ Dependent variable $=\Delta \ln Y$} \\
\hline & Morocco & Oman & Qatar & Saudi Arabia \\
\hline \multirow{2}{*}{$E C M_{t-1}$} & $-0.226 * * *$ & $0.411 * * *$ & $-0.519 * * *$ & $-0.151 * *$ \\
\hline & $(-25.425)$ & $(39.584)$ & $(-5.065)$ & $(-2.878)$ \\
\hline \multirow[t]{2}{*}{$\Delta \ln Y_{t-1}$} & $-0.425^{*}$ & -0.213 & $-0.628 * * *$ & $0.510^{* *}$ \\
\hline & $(-1.998)$ & $(-1.048)$ & $(-5.295)$ & $(2.590)$ \\
\hline \multirow{2}{*}{$\Delta \ln K_{t-1}$} & $0.605^{*}$ & -0.443 & $0.204 * * *$ & 0.210 \\
\hline & $(1.685)$ & $(-0.746)$ & $(3.847)$ & $(1.181)$ \\
\hline \multirow[t]{2}{*}{$\Delta \ln L_{t-1}$} & $0.429 *$ & 0.494 & $1.782 * *$ & -0.006 \\
\hline & $(1.677)$ & $(1.264)$ & $(3.567)$ & $(-0.014)$ \\
\hline \multicolumn{5}{|c|}{ Exogenous variables } \\
\hline \multirow[t]{2}{*}{$D U M$} & $0.043^{* *}$ & $0.122 * * *$ & $0.071 * * *$ & 0.039 \\
\hline & $(2.321)$ & $(4.278)$ & $(3.433)$ & $(1.211)$ \\
\hline \multirow[t]{2}{*}{ INF } & 0.002 & 0.006 & $-0.002 * *$ & 0.003 \\
\hline & $(0.425)$ & $(1.308)$ & $(-2.041)$ & $(0.709)$ \\
\hline \multirow[t]{2}{*}{$E D U$} & $0.048 * * *$ & $0.039 * * *$ & $0.063^{* *}$ & $0.019 *$ \\
\hline & $(4.458)$ & $(4.090)$ & $(2.613)$ & $(1.725)$ \\
\hline \multirow[t]{2}{*}{ Constant } & $0.135^{* *}$ & $-0.179 * * *$ & $0.631 * * *$ & $-0.176^{* *}$ \\
\hline & $(2.452)$ & $(-4.054)$ & $(4.137)$ & $(-2.059)$ \\
\hline$R^{2}$ & 0.979 & 0.987 & 0.976 & 0.960 \\
\hline $\operatorname{Adj} \cdot R^{2}$ & 0.972 & $0 . .982$ & 0.935 & 0.663 \\
\hline Standard error & 0.039 & 0.061 & 0.013 & 0.058 \\
\hline AIC & -3.392 & -2.501 & -5.573 & -2.612 \\
\hline F-stat & $140.340^{* * *}$ & $231.523 * * *$ & $24.007 * *$ & $5.904 *$ \\
\hline
\end{tabular}

Note. i) ***, ** and * implies significant at $1 \%, 5 \%$ and $10 \%$ level respectively.

ii) Figures in parenthesis represent the t-statistics.

\section{Concluding Remarks}

The overall growth performance of the MENA countries has been both mixed and characterized by a higher degree of volatility in comparison with oil exporter countries and non-oil countries. Several sources of uncertainty in the region can explain this volatility. These include, among others, fluctuations in world oil prices, investment (capital flows) and factors contributing the socio-political instability in the region such as civil wars and regional conflicts such as Golf -War and Iranian revolution.

The analysis covers a sample of 15 MENA countries of which (including MENA oil countries, and non-oil MENA countries) had complete data for all variables.

The objective of this chapter, as mentioned in the introduction, is first to see the main source of growth in the North Africa and Middle-East countries by applying Cobb-Douglas specification, and second to check for robustness of any relationship that may exist in the short and long-run by applying Johansen Co-integration, Error Correction Model (ECM) methods, and Impulse Response Function (IRF). That is likely to persist in these three variables $\Delta \ln Y, \Delta \ln K$ and $\Delta \ln K$. In this chapter the above objective is attained in the following way: first of all, we have estimated the initial capital stock by applying several approaches to get a series of capital $(K)$. Also, we test for stationarity by applying conventional unit root test (ADF) without considering the existence of potential structural break, then we test for unit root in the presence of potential structural break by applying different approaches (DF-GLS and KPSS) in order to examine the stationarity of the data with unknown structural break. A variety of specifications are estimated, Johansen Co-integration estimation for a long-run relationship, and Error Correction Model for short-run relationship by taking in our consideration the structural break. Both estimations provide the most reliable results for some countries after we include dummy variable for some countries where the oil prices can affect the growth of real GDP.

The variables selected in this chapter for all of these different estimators are summarised in Table 1, 2 and 3. The main conclusion is that the growth of $K$ in some oil MENA countries generally grows faster than the growth of $L$ in some countries. Contrarily, in non-oil countries labour is a quit grows faster than capital. That is of course due to some factors such as increase of the growth of population in some countries such as Egypt, Jordan and Tunisia. I conclude from my results that some MENA countries like Qatar, Saudi Arabia and United Arab Emirates the 
aggregate production function does not appear to be Cobb-Douglas.

This relationship remains robust even after allowing the (IRF) to be jointly determined in a system. The estimated of the production function is for a long-run and short-run; however, these estimates are in line with the estimated in previous studies as mentioned in the literature. The signs of the estimated of growth of $K$ andgrowth of $L$ with respect to real GDP has been interpreted as follows: firstly, in the long-run the increases in $\Delta \ln K$ in some countries will lead to increase in output, simply because more investment will lead to increase of growth of RGDP. A similar result is reported by Adams and Felipe (2005), though the coefficient there was not significant. Secondly, the short-run relationship as reported in table 2. It shows the results of the Error Correction Mechanism (ECM) term, and it represents the speed of adjustment back to the long-run relationship among the variables for 15 countries under study for real GDP growth $\Delta \ln R G D P$. The estimated co-efficient shows the immediate impact of inputs $\Delta \ln k, \Delta \ln k$ and inf, $e d u$ as exogenous variables on $\Delta \ln R G D P$. The ECM terms are significant for our entire sample.

In the short-run increase in education measured by secondary schooling years, is associated with higher increase of growth of real GDP, because this improves the skills opportunities of employees in the future. However, an increase in education leads to increase in the output.

\section{References}

Aamer, S., Abu-Qarn, N., \& Abu-Bader, S. (2007). Sources of growth revisited: Evidence from selected MENA countries. World Development, 35(5), 752-771. https://doi.org/10.1016/j.worlddev.2006.08.004

Akinlo, A. E. (2006). The stability of money demand in Nigeria: An autoregressive distributed lag approach. Journal of Policy Modelling, 28, 445-452. https://doi.org/10.1016/j.jpolmod.2005.09.001

Arellano, M., \& Bover, O. (1995). Another look at the instrumental-variable estimation of error-components models. Journal of Econometrics, (68), 29-52. https://doi.org/10.1016/0304-4076(94)01642-D

Barro, R., \& Lee, J. (2001). International data on educational attainment: Updates and implications. Oxford Economic Papers, 3, 541-563. https://doi.org/10.1093/oep/53.3.541

Becker, G. S., \& Chiswick, R. (1966). Education and the distribution of earnings. The American Economic Review, 56(1), 358-69.

Becker, G. S., Edward, L., \& Murphy, G. (1999). Population and economic growth. American Economic Review, 89(2), 145-149. https://doi.org/10.1257/aer.89.2.145

Blanchard, O. (1984). The Lucas critique and the Volcker deflation. The American Economic Review, 74(2), 211-5. https://doi.org/10.3386/w1326

Bureau for Arab States. (2018). The Arab Human Development Report 2005: Towards the rise of women in the Arab world, 2018. United Nations Development Programme, Bureau for Arab States, New York.

Claus, B. (2000). Is the output gap a useful indicator of inflation? Reserve Bank of New Zealand Discussion Paper.

Cobb, W., \& Douglas, H. (1928). A theory of production. The American Economic Review, 18, 139-65.

Coe, D., \& McDemott, J. (1997). Does the gap model work in Asia? International Monetary Fund Staff Papers, (44), 59-80. https://doi.org/10.2307/3867497

Cohen, D., \& Soto, M. (2007). Growth and human capital: Good data, good results. Springer Science and Business, 3, 52-76. https://doi.org/10.1007/s10887-007-9011-5

Dholakia, R. H. (1990). Extended Phillips curve for the Indian economy. Indian Journal, 38(1), 69-78.

Dickey, D., \& Fuller, W. (1981). Likelihood ratio test for autoregressive time series with a unit root. Econometrica, 49(4), 57-107. https://doi.org/10.2307/1912517

Durlauf, S., Johanson, P., \& Temple, J. (2005). Growth Econometrics. Handbook of Economic Growth, 8(1), 555-577. https://doi.org/10.1016/S1574-0684(05)01008-7

Easterly, W., Levine, R., \& Roodman, D. (2004). New data, new doubts: A comment on Burnside and Dollar's aid policies and growth. The American Economic Review, (94), 774-780. https://doi.org/10.1257/0002828041464560

Gerlach, S., \& Yiu, M. (2004). Estimating output gaps in Asia: A cross-country study. Journal of the Japanese and International Economies, (18), 115-136. https://doi.org/10.1016/S0889-1583(03)00033-9 
Hansen, M., \& Pancs, R. (2001). The Latvian labour market transition: the Beveridge and Phillips curve as indicators of normalization. BICEPS Working Paper.

Keller, J., \& Nabli, K. (2002). The Macroeconomic of labour market outcomes in MENA over the 1990s: how growth has failed to keep pace with a burgeoning labour market. Egyptian Centre For Economic Studies Working Paper, (71).

Lee, J. (2000). The robustness of Okun's Law: Evidence from OECD countries. Journal of Macroeconomics, 22, 331-356. https://doi.org/10.1016/S0164-0704(00)00135-X

Lipsey, R. G. (1960). The relation between unemployment and the rate of change of money wage rate in the United Kingdom, 1962-1957: A further analysis. Economica, 25, 282-299. https://doi.org/10.2307/2551424

Moosa, I. (1999). Cyclical output, cyclical unemployment, and Okun's coefficient: A structural time series

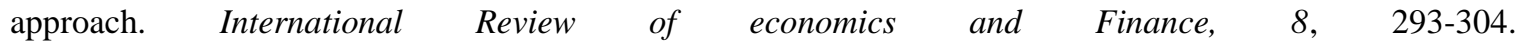
https://doi.org/10.1016/S1059-0560(99)00028-3

Nabli, M. K. (2004). Long term economic development challenges and prospects for the Arab countries. Paper presnted at the Conference of the Institute du Monde, Paris. https://doi.org/10.1596/28427

Rao, B., \& Cooray, A. (2008). How useful is the theoretical and empirical growth literature for policies in the developing countries? Economic and Econometric Institute Research Paper Series, EERI RP 200809.

Rao, B., \& Hassan, G. (2011). Determinants of the long-run growth rate of Bangladesh. Applied Economics Letters, Forthcoming. https://doi.org/10.1080/13504851003800760

Romer, P. (1986). Increasing returns and long-run growth. Journal of Political Economy, 94(5), 1002-1037. https://doi.org/10.1086/261420

Rudd, J., \& Whelan, K. (2005). Does labour's share drive inflation? Journal of Money Credit and Banking, 37(2), 298-312. https://doi.org/10.1353/mcb.2005.0023

Senhadji, A. (2000). Source of economic growth: an extensive growth accounting exercise. International Monetary Fund Staff Papers, 47, 129-157.

Solow, R. (1956). A contribution to the theory of economic growth. Quarterly Journal of Economics, (70), 65-94. https://doi.org/10.2307/1884513

\section{Note}

Note 1. Schooling data from Barro and Lee(2010) are available only every five years, so we can use linear interpolation in between.

\section{Appendix A. Impulse Response Functions}

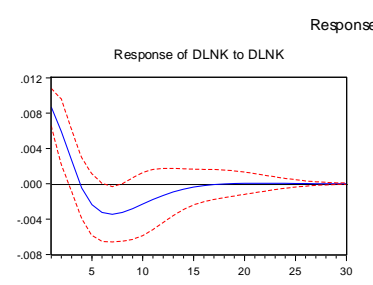

Response of DLNL to DLNK

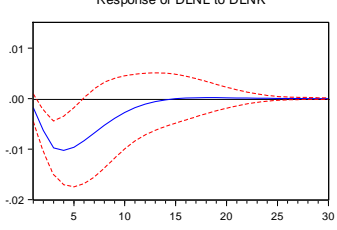

Response of DLNY to DLNK

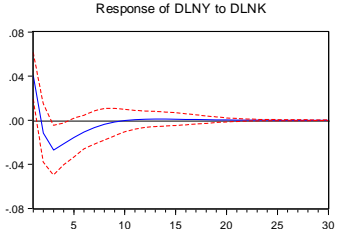

Response to Cholesky One S.D. Innovations \pm 2 S.E for Uinted Arab Emirates

Response of DLNK to DLNL

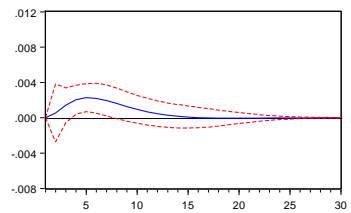

Response of DLNL to DLNL

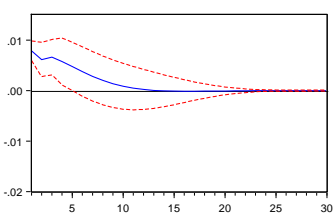

Response of DLNY to DLNL

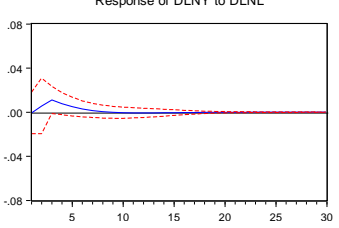

Response of DLNK to DLNY

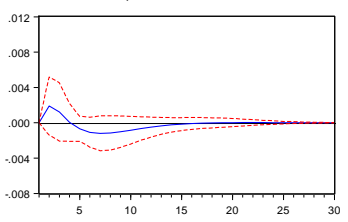

Response of DLNL to DLNY

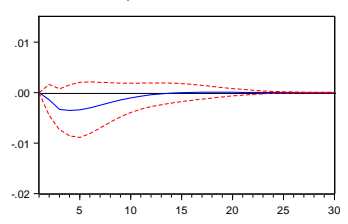

Response of DLNY to DLNY

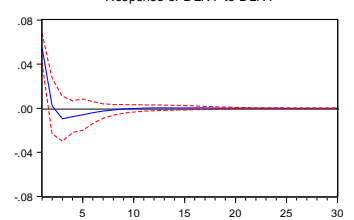


Appendix B. Critical value of different unit root test

\begin{tabular}{cccccc}
\hline & \multicolumn{2}{c}{ ADF } & \multicolumn{2}{c}{ DF-GLS } & KPSS \\
\cline { 2 - 6 } & C & C \& T & C & C \& & C \\
\hline 1\% level & -3.621 & -4.147 & -2.618 & -3.770 & 0.739 \\
5\% level & -2.943 & -3.517 & -1.948 & -3.190 & 0.463 \\
10\% level & -2.610 & -3.185 & -1.612 & -2.890 & 0.347 \\
\hline
\end{tabular}

Source: Eviews 7 calculation.

Note. The lag length of ADF and KPSS a test are AIC, but for DF-GLS is SIC.

Unit root test include intercept (C) and trend (T), but for KPSS test we report constant only (C).

\section{Appendix C. Definition of variables and sources: world Bank, IMF, KILM, Penn World Bank, UN and Barro-Lee data}

\begin{tabular}{|c|c|c|}
\hline Variables & Definition & Source \\
\hline RGDP (Y) & $\begin{array}{l}\text { Real Gross Domestic Product. GDP at purchaser's prices is sum of } \\
\text { gross value added by all resident producers in the economy plus any } \\
\text { product taxes and minus any subsidies not included in the value of } \\
\text { products. The value in constant US } 2000 \text { U.S dollars. }\end{array}$ & World Development Indicators (WDI) 2010 \\
\hline CPI & Consumer price at constant year of 2005 & World Development Indicators, 2010 \\
\hline INF & Inflation rate & $\begin{array}{l}\text { World Bank national account data (World } \\
\text { Development Indicators, 2010) }\end{array}$ \\
\hline $\mathrm{INV}(\mathrm{GFCF})$ & Real investment From (IRAT*RGDP)/100 & $\begin{array}{l}\text { World Bank (World Development } \\
\text { Indicators, } 2010\end{array}$ \\
\hline K & $\begin{array}{l}\text { Capital Stock; derived using perpetual inventory method (depreciation } \\
=0.05) \\
K_{t}=\left(1-\delta_{k}\right) K_{t-1}+K_{t-1}\end{array}$ & World development indicators(WDI) 2010 \\
\hline Dummy & $\begin{array}{l}\text { This is oil dummy variables take a value of } 0 \text { for oil MENA countries } \\
\text { when there are changes in oil prices and one otherwise. }\end{array}$ & Computed by author \\
\hline EDU & $\begin{array}{l}\text { Average years of secondary schooling among population aged over } 25 \\
\text { years }\end{array}$ & Barro and Lee (2010) database \\
\hline K & $\begin{array}{l}\text { Capital stock; derived using perpetual inventory method } \\
K_{t}=K_{0} * 0.95+I_{t} \\
I_{t} \quad \text { is real gross domestic fixed investment (the depreciation is } 0.05 \text { ) }\end{array}$ & $\begin{array}{l}\text { International Monetary } \text { Fund } \quad \text { (IMF) } \\
\text { database, 2010 }\end{array}$ \\
\hline
\end{tabular}

\section{Copyrights}

Copyright for this article is retained by the author(s), with first publication rights granted to the journal.

This is an open-access article distributed under the terms and conditions of the Creative Commons Attribution license (http://creativecommons.org/licenses/by/4.0/). 